obtained in the final 14 days of each 21-day period. The patients' own general assessment of each treatment is based upon the whole 21-day periods and scored on a five-point scale in the following way: -1 worsening of the angina $;+1,+2$, and +3 indicating slight, moderate, and marked improvement respectively; and 0 showing that the condition had remained unchanged when compared with that before the start of the trial. The results are summarized in Tables I and II.

TABLE II.-Summarized Results and Statistical Analysis of Trial

\begin{tabular}{|c|c|c|c|c|c|}
\hline \multicolumn{2}{|c|}{ Criterion } & \multirow{2}{*}{$\mid$\begin{tabular}{c|} 
Propranolol \\
$\begin{array}{c}4 \cdot 40 \\
0-14\end{array}$
\end{tabular}} & \multirow{2}{*}{$\begin{array}{c}\text { Placebo } \\
\begin{array}{l}3.55 \\
0-14\end{array}\end{array}$} & \multirow{2}{*}{$\begin{array}{c}\text { Difference } \\
\begin{array}{c}0.85 \pm 1 \cdot 08 \\
-11 \pm+10\end{array}\end{array}$} & \multirow{2}{*}{$\frac{t-\text { Value }}{0.8 \mathrm{NS}}$} \\
\hline Days pain free & $\cdots\left\{\begin{array}{l}\text { mean } \\
\text { range }\end{array}\right.$ & & & & \\
\hline No. of attacks & $\cdots\left\{\begin{array}{l}\text { mean } \\
\text { range }\end{array}\right.$ & $\begin{array}{l}35 \cdot 5 \\
0-300\end{array}$ & $\begin{array}{l}43: 3 \\
0-350\end{array}$ & $\begin{array}{c}-7 \cdot 8 \pm 4 \cdot 4 \\
-50-+31\end{array}$ & $\begin{array}{c}1.74 \\
0.1>\mathrm{P} \\
>0.05 \mathrm{NS}\end{array}$ \\
\hline TNT tablets & $\ldots\left\{\begin{array}{l}\text { mean } \\
\text { range }\end{array}\right.$ & $\begin{array}{l}26 \cdot 3 \\
0-89\end{array}$ & $\begin{array}{l}29 \cdot 1 \\
0-129\end{array}$ & $\begin{array}{l}-2 \cdot 8 \pm 5 \cdot 4 \\
-41-+62\end{array}$ & $0.5 \mathrm{NS}$ \\
\hline \multirow{2}{*}{\multicolumn{2}{|c|}{$\begin{array}{l}\text { Average No. of days }\left\{\begin{array}{l}\text { better } \\
\text { same } \\
\text { worse }\end{array}\right. \\
\text { Patients' general assessments } \\
\text { of angina }\end{array}$}} & $\begin{array}{l}9 \cdot 1 \\
3 \cdot 7 \\
1 \cdot 3\end{array}$ & $\begin{array}{l}7 \cdot 5 \\
5 \cdot 1 \\
1 \cdot 5\end{array}$ & & \\
\hline & & $+1 \cdot 35$ & +0.75 & $+0.60 \pm 0.37$ & $P>0.1 \mathrm{NS}$ \\
\hline
\end{tabular}
* Based upon the following five-point scale for the full 21-day periods: Worse $=$
-1 , No change $=0$, Slight improvement $=+1$, Moderate improvement $=+2$, Marked improvement $=+3$.

\pm Figures indicate standard errors based on within-patient comparisons.

Values not statistically significant.

Values not statistically significant but near the $5 \%$ or $10 \%$ level of significance are indicated as $\mathbf{P}>0.05$ and $\mathbf{P}>0.1$ respectively.

\section{Discussion}

It will be seen from Table II that, by all the criteria used, the trial failed to show any statistically significant difference between the drug and the placebo, although the reduction in the number of anginal attacks approached a $5 \%$ level of significance in favour of the drug. The patients' own general assessments showed a similar trend. Indeed, if the seven patients who failed to detect any difference between the drug and the placebo are excluded, the analysis reveals that 11 favoured the drug and only two the placebo.

The number of attacks of angina in the 14-day records varied considerably from patient to patient, and Table I shows that those patients with the largest number of attacks (Nos. 3, 4, 16, and 20, all of whom had more than 50 attacks per 14-day period) derived no benefit at all. These were all cases with angina of long standing, and it is possible that such cases are particularly resistant to this therapy.

Propranolol appears to cause fewer side-effects than pronethalol, and when they occur they respond easily to a reduction in the dose. Whether better results could be obtained with higher doses of propranolol has not been explored in this trial, but the limiting factor in dosage is likely to be not so much toxicity as the tendency of beta-adrenergic blocking compounds to induce circulatory failure by excessive weakening of the force of contraction of heart muscle. Further observations on safe dosage are probably still needed.

It is concluded that the drug is of some value in the treatment of angina except perhaps in chronic severe cases, and a more extended trial would be fully justified.

\section{Summary}

A double-blind trial has been carried out with propranolol (I.C.I. 45520, Inderal) on 20 patients suffering from angina of effort. Although favourable results in this small series did not achieve statistical significance, they showed sufficient promise to justify a more extended trial. Symptomatic side-effects were few and transient, and no toxic effects on the urine, blood count, or liver-function were noted.

Our thanks are due to Mr. H. Poole and his staff of the Pharmacy Department of the Royal Victoria Infirmary for their help in the trial, to the patients who took part in it, and to I.C.I. Pharmaceuticals Ltd. for the supply of the tablets used.

\section{REFERENCES}

Alleyne, G. A. O., Dickinson, C. J., Dornhorst, A. C., Fulton, R. M. Green, K. G., Hill, I. D., Hurst, P., Laurence, D. R., Pilkington, T., Prichard, B. N. C., Robinson, B., and Rosenheim, M. L. (1963). Brit. med. $7 ., 2,1226$.

Black, J. W., Crowther, A. F., Shanks, R. G., Smith, L. H., and Dornhorst, A. C. (1964). Lancet, 1, 1080.

\title{
Use of Propranolol (Inderal) in Treatment of Hypertension
}

\author{
B. N. C. PRICHARD,* M.SC., M.B., B.S. ; P. M. S. GILLAM, † M.B., M.R.C.P.
}

Pronethalol has a hypotensive action in man when given orally over a period of three months, though no effect was seen after acute intravenous injection. In addition, short-term administration in a double-blind trial of pronethalol in angina pectoris (Prichard, Dickinson, Alleyne, Hurst, Hill, Rosenheim, and Laurence, 1963) produced a small but significant hypotensive effect (Prichard, 1964). Fifteen patients were given pronethalol for three months ; they showed an average fall of supine bloodpressure of $33 / 23 \mathrm{~mm}$. $\mathrm{Hg}$, standing $27 / 16 \mathrm{~mm}$. Hg. This hypotensive action of pronethalol was not further investigated in view of its tumour-producing action in mice (Paget, 1963).

The animal pharmacology of pronethalol was reported by Black and Stephenson (1962). It was the first specific

\footnotetext{
* Lecturer in Pharmacology and Therapeutics, Medical Unit, University College Hospital Medical School, London.

† Formerly Senior Registrar. Medical Unit, University College Hospital now Senior Registrar, Whittington Hospital, London.
}

adrenergic beta-receptor-blocking drug, blocking the increased rate and force of contraction of the heart and relaxation of smooth muscle that result from the administration of adrenaline or isoprenaline. The classical adrenergic blocking drugs, such as ergot and phenoxybenzamine, block the alpha effects of adrenaline and noradrenaline, preventing the vasoconstriction seen in certain vascular sites. Pronethalol has no such action and the effect in man is consistent with beta-receptor blockade. It abolishes the dilatation of the forearm blood-vessels following intra-arterial isoprenaline and it alters the response to intravenous adrenaline so that it resembles that of noradrenaline (Dornhorst and Robinson, 1962). It reduces the reflex tachycardia during Valsalva's manœuvre and diminishes the overshoot that follows the release of effort (Prichard, 1964).

Black, Crowther, Shanks, Smith, and Dornhorst (1964) briefly described the pharmacology of the closely related drug propranolol (I.C.I. 45,520, Inderal). It was reported to have 
a beta-receptor blocking action in animals and man and to be about ten times as potent as pronethalol. It does not produce tumours in mice. The present paper concerns initial experience of the hypotensive action of propranolol in out-patients.

\section{Patients, Methods, and Dosage}

Propranolol has been given to 23 patients for two months or more. Seven were normotensive patients who received propranolol for angina pectoris ; in addition, 7 of the 16 hypertensive patients also had angina. Four patients were hitherto untreated hypertensives, three were transferred from other hypotensive drugs, while in nine propranolol was added to existing therapy, to improve blood-pressure control or because of angina.

The hypertensive patients were seen by the same physicians at each visit. The first physician asked standard questions, recorded the patient's subjective symptoms, and adjusted the dose of propranolol. The second physician, unaware of the dose that the patient was receiving, took the patient's bloodpressure under the same conditions at each visit. Patients were seen fortnightly at first, then every month or six weeks. The patients with angina were seen fortnightly and assessed by the same physician at each visit.

The anginal patients were given from 80 to $400 \mathrm{mg}$. daily in divided doses, the remaining hypertensive patients from 30 to $160 \mathrm{mg}$. daily. The initial dose was $10 \mathrm{mg}$. three or four times a day, increments of 5 to $10 \mathrm{mg}$. per dose being made at each visit as required. The higher dosage that we are using in some anginal patients is a result of the trial design, which is similar to that used in the study of pronethalol (Prichard et al., 1963).

One 71-year-old woman suffering from angina pectoris developed symptoms of heart failure two days after starting propranolol (10 mg. q.d.s.). The drug was stopped and the symptoms cleared within three days without other treatment. Anginal patients who were thought to be at risk of developing congestive cardiac failure have therefore received smaller increments.

\section{Results}

The effects of propranolol administration on the bloodpressure in hypertensives are summarized in Table I, in normotensives in Table II.
The seven hypertensive patients who were given propranolol alone all achieved supine and standing diastolic pressures of $100 \mathrm{~mm}$. $\mathrm{Hg}$ or less. One of these patients who was given propranolol primarily for angina was only very mildly hypertensive with neither fundal nor E.C.G. changes. Five patients on guanethidine, or bethanidine, or methyldopa all had considerable further reduction of blood-pressure following the addition of propranolol. Four of the remaining five patients, on milder hypotensive drugs, had some reduction in bloodpressure. In only 1 of the 16 hypertensive patients on propranolol was the standing blood-pressure above $100 \mathrm{~mm} . \mathrm{Hg}$, and in only two in the supine position. A small fall of bloodpressure was recorded in five of the seven normotensive patients.

In 8 of the 11 patients who received no other hypotensive drugs pulse rates were recorded prior to propranolol administration and at the time of the most recent blood-pressure reading; in all of these there was a fall in supine and erect pulse. In the remaining patients the position is less clear owing to the concurrent administration of other drugs.

No added hypotension on exercise (two flights of stairs) has been noted in those hypertensive patients without angina on propranolol whose blood-pressure was well controlled with or without other drugs (Cases 1, 3, 4, 6, 7, 9, and 10).

Subjective Feelings and Side-effects.-In response to standard questions 20 of the 23 patients felt well on the dose listed in the Tables. Two patients felt a little tired at their last visit ; one patient felt unwell because of an intercurrent illness. The sole side-effect seen at dosages below $200 \mathrm{mg}$. daily was slight tiredness in two patients; no other side-effects have been seen in any of the hypertensive patients. In normotensive patients with the larger doses used in our anginal trial the following side-effects have been recorded ; (1) on $50 \mathrm{mg}$. q.d.s., one patient had transient depression, one felt giddy and unsteady; $(2)$ on $70 \mathrm{mg}$. q.d.s. one patient felt irritable and had cramp in the chest ; (3) on $80 \mathrm{mg}$. q.d.s. one patient felt nauseated, one has

\begin{tabular}{|c|c|c|c|c|c|c|c|c|}
\hline \multirow{2}{*}{$\begin{array}{l}\text { Case } \\
\text { No. }\end{array}$} & \multirow{2}{*}{ Sex } & \multirow{2}{*}{ Age } & \multicolumn{2}{|c|}{ Pre-Therapy B.P. } & \multicolumn{2}{|c|}{ Latest B.P. } & \multirow{2}{*}{$\begin{array}{l}\text { Dose } \\
\text { (mg./ } \\
\text { day) }\end{array}$} & \multirow{2}{*}{$\begin{array}{c}\text { Treatment } \\
\text { Months }\end{array}$} \\
\hline & & & Supine & Erect & Supine & Erect & & \\
\hline $\begin{array}{l}17 \\
18 \\
19 \\
20 \\
21 \\
22 \\
23\end{array}$ & $\begin{array}{l}M \\
M \\
F \\
M \\
M \\
M \\
M\end{array}$ & $\begin{array}{l}42 \\
66 \\
60 \\
63 \\
44\end{array}$ & $\begin{array}{l}100 / 60 \\
135 / 90 \\
140 / 80 \\
174 / 90 \\
155 / 90 \\
118 / 80 \\
135 / 90\end{array}$ & $\begin{array}{r}98 / 60 \\
110 / 85 \\
135 / 80 \\
170 / 90 \\
116 / 76 \\
140 / 80\end{array}$ & $\begin{array}{r}90 / 55 \\
130 / 70 \\
135 / 70 \\
170 / 80 \\
125 / 70 \\
90 / 55 \\
115 / 65\end{array}$ & $\begin{array}{r}90 / 60 \\
110 / 70 \\
120 / 70 \\
160 / 90 \\
110 / 70 \\
90 / 65 \\
100 / 70\end{array}$ & $\begin{array}{r}160 \\
160 \\
320 \\
280 \\
280 \\
240 \\
80\end{array}$ & $\begin{array}{l}7 \\
6 \frac{1}{2} \\
5 \\
5 \\
4 \frac{1}{2} \\
4 \\
4\end{array}$ \\
\hline
\end{tabular}

TABLE I.-Hypertensives

\begin{tabular}{|c|c|c|c|c|c|c|c|c|c|c|c|c|c|c|}
\hline \multirow{2}{*}{$\begin{array}{l}\text { Case } \\
\text { No. }\end{array}$} & \multirow{2}{*}{ Group } & \multirow{2}{*}{ Sex } & \multirow{2}{*}{ Age } & \multirow{2}{*}{ Fundus } & \multirow{2}{*}{ E.C.G. } & \multicolumn{2}{|c|}{ Pre-Therapy B.P. } & \multicolumn{2}{|c|}{$\begin{array}{l}\text { B.P. on Previous } \\
\text { Therapy }\end{array}$} & \multicolumn{2}{|c|}{ Latest B.P. } & \multirow{2}{*}{$\begin{array}{l}\text { Dose } \\
\text { (mg./ } \\
\text { day) }\end{array}$} & \multirow{2}{*}{$\begin{array}{l}\text { Treatment } \\
\text { Months }\end{array}$} & \multirow{2}{*}{$\begin{array}{l}\text { Reason for } \\
\text { Administering } \\
\text { Propranolol }\end{array}$} \\
\hline & & & & & & Supine & Erect & Supine & Erect & Supine & Erect & & & \\
\hline $\begin{array}{l}1 \\
2 \\
3 \\
4\end{array}$ & & $\begin{array}{l}\dot{M} \\
M \\
\mathrm{~F} \\
\mathrm{~F}\end{array}$ & $\begin{array}{l}57 \\
60 \\
39 \\
60\end{array}$ & $\begin{array}{l}\text { I } \\
0 \\
0 \\
\text { II }\end{array}$ & $\begin{array}{l} \pm \\
\pm \\
-\end{array}$ & $\mid \begin{array}{c}1 . P \\
190 / 120 \\
170 / 100 \\
180 / 100 \\
200 / 105\end{array}$ & 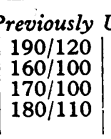 & $\begin{array}{c}\text { Untreated } \\
- \\
- \\
-\end{array}$ & $\bar{z}$ & $\begin{array}{l}130 / 70 \\
150 / 80 \\
150 / 80 \\
190 / 100\end{array}$ & $\begin{array}{l}130 / 90 \\
145 / 80 \\
130 / 80 \\
150 / 100\end{array}$ & $\begin{array}{l}120 \\
400 \\
160 \\
140\end{array}$ & $\begin{array}{l}5 \\
5 \\
3 \\
2\end{array}$ & $\begin{array}{l}\text { New patient } \\
\text { Angina } \\
\text { New patient } \\
\text { New patient }\end{array}$ \\
\hline \multicolumn{15}{|c|}{ 2. Changed from Other Drugs } \\
\hline $\begin{array}{l}5 \\
6\end{array}$ & $\begin{array}{l}\text { Reserpine } \\
\text { Methyldopa }\end{array}$ & $\stackrel{M}{M}$ & $\begin{array}{l}61 \\
42\end{array}$ & II & $\overline{+}$ & $\left|\begin{array}{l}190 / 110 \\
230 / 135\end{array}\right|$ & - & $\left|\begin{array}{l}156 / 90 \\
155 / 110\end{array}\right|$ & $\begin{array}{l}158 / 90 \\
155 / 115\end{array}$ & $\left|\begin{array}{l}125 / 70 \\
145 / 100\end{array}\right|$ & $\begin{array}{l}110 / 80 \\
125 / 100\end{array}$ & $\begin{array}{l}320 \\
160\end{array}$ & $3^{\frac{1}{3}}$ & $\begin{array}{l}\text { Angina } \\
\text { Tiredness on } \\
\text { methyldopa }\end{array}$ \\
\hline 7 & Guanethidine & $\mathbf{M}$ & 52 & II & + & * & & $165 / 100$ & $150 / 110$ & $160 / 80$ & $135 / 85$ & 120 & 2 & Control not good \\
\hline \multicolumn{15}{|c|}{ 3. Other Drugs Continued } \\
\hline $\begin{array}{l}8+ \\
9\end{array}$ & $\begin{array}{l}\text { Guanethidine } \\
\text { Guanethidine }\end{array}$ & $\stackrel{\mathrm{M}}{\mathrm{F}}$ & $\begin{array}{l}51 \\
53\end{array}$ & I & $\overline{+}$ & $\left|\begin{array}{l}190 / 130 \\
270 / 150\end{array}\right|$ & $26 \overline{160}$ & $\left|\begin{array}{l}190 / 120 \\
200 / 100\end{array}\right|$ & $\begin{array}{l}160 / 110 \\
180 / 105\end{array}$ & $\left|\begin{array}{l}145 / 85 \\
190 / 100\end{array}\right|$ & $\begin{array}{l}110 / 90 \\
145 / 95\end{array}$ & $\begin{array}{r}240 \\
80\end{array}$ & $\begin{array}{l}4 \\
3\end{array}$ & $\begin{array}{l}\text { Angina } \\
\text { Fair control on } \\
\text { guanethidine }\end{array}$ \\
\hline 10 & Guanethidine & $\mathbf{F}$ & 54 & II & + & $250 / 150$ & - & $230 / 126$ & $194 / 116$ & $220 / 116$ & $144 / 94$ & 30 & $2 \frac{1}{2}$ & Diarrhoea on larger \\
\hline 11 & Bethanidine & $\mathrm{F}$ & 67 & II & - & $230 / 125$ & $230 / 150$ & $220 / 115$ & $185 / 130$ & $170 / 123$ & $163 / 106$ & 80 & $2 \frac{1}{2}$ & Dizziness on larger \\
\hline 12 & $\begin{array}{l}\text { Methyldopa }+ \text { hydro- } \\
\text { chlorothiazide }\end{array}$ & $\mathbf{M}$ & 45 & IV & + & $250 / 160$ & - & $170 / 115$ & $150 / 120$ & $120 / 80$ & $110 / 85$ & 200 & 2 & Angina \\
\hline 13 & $\begin{array}{l}\text { Chlorothiazide }+ \\
\text { reserpine }\end{array}$ & $F$ & 58 & II & - & $210 / 120$ & - & $140 / 84$ & $132 / 86$ & $155 / 90$ & $150 / 85$ & 120 & $6 \frac{1}{2}$ & Angina \\
\hline $\begin{array}{l}14 \\
15\end{array}$ & $\begin{array}{l}\text { reserpine } \\
\text { Chlorothiazide } \\
\text { Chlorothiazide }\end{array}$ & $\underset{F}{F}$ & $\begin{array}{l}62 \\
49\end{array}$ & $\begin{array}{l}\text { II } \\
\text { II }\end{array}$ & \pm & $\begin{array}{l}190 / 130 \\
220 / 120\end{array}$ & $22 \overline{1} / 10$ & \begin{tabular}{|l}
$158 / 98$ \\
$194 / 96$
\end{tabular} & $\begin{array}{l}168 / 100 \\
178 / 106\end{array}$ & $\begin{array}{l}150 / 90 \\
180 / 85\end{array}$ & $\begin{array}{l}130 / 85 \\
165 / 80\end{array}$ & $\begin{array}{l}80 \\
80\end{array}$ & $\begin{array}{l}5 \\
3 \frac{1}{2}\end{array}$ & $\begin{array}{l}\text { Angina } \\
\text { Fair control on } \\
\text { chlorothiazide } \\
\text { alone }\end{array}$ \\
\hline 16 & Reserpine & $\mathbf{M}$ & 57 & I & - & $200 / 125$ & - & $208 / 90$ & $182 / 96$ & $170 / 90$ & $155 / 90$ & 400 & 7 & Angina \\
\hline
\end{tabular}


felt tired, one had visual hallucinations of coloured lights on this dose. This latter side-effect also occurred after five weeks on $100 \mathrm{mg}$. q.d.s. These side-effects were all readily relieved by reducing the dose. Two of the hypertensive anginal patients on $400 \mathrm{mg}$. daily have not experienced any side-effects: we have not increased the dose above this level.

\section{Discussion}

Fifteen out of 16 hypertensive patients given 'propranolol for up to seven months have shown reductions of blood-pressure. Propranolol alone may prove to be useful in the treatment of mild and moderately severe cases of hypertension. In one patient experiencing marked drowsiness on methyldopa a change to propranolol resulted in improved blood-pressure control with no side-effects. Propranolol produced a considerable hypotensive effect in patients on adrenergic neurone-blocking and milder hypotensive drugs.

Propranolol has so far proved relatively free from side-effects and patients usually feel well on the drug. We have seen one case where heart failure was precipitated by propranolol; this has been reported following pronethalol (Stock and Dale, 1963). We consider that propranolol should be used with great caution, if at all, in patients with a history suggestive of heart failure, though one such patient with severe angina responded well without trouble. The only other side-effect in the dosage recommended for the treatment of hypertension, up to $200 \mathrm{mg}$. a day in divided dosage, has been slight tiredness in 2 of the 23 patients, readily relieved by reduction of the dosage. The side-effects seen with larger doses used in our angina trial have also been relieved by reducing the dose.

While a central mode of action is not excluded it is suggested that beta-receptor-blocking drugs exert their hypotensive action by blocking the sympathetic receptors in the heart. A feature of both pronethalol (Prichard, 1964) and propanolol (Tables I and II) has been the absence of postural hypotension. In all of the 14 patients (Cases 1-7, 17-23) receiving propranolol alone there is a rise or no change in the diastolic pressure on standing. This would be expected, as the response of the cardiovascular system to the effect of gravity is chiefly mediated by increasing sympathetic (alpha) vasoconstrictor tone.

Pronethalol given intravenously does not exert any significant effect on the blood-pressure (Dornhorst and Robinson, 1962 ; Prichard, 1964) and our preliminary results suggest that the closely related drug propranolol also has no effect (Hodge and Prichard, unpublished data). Pronethalol immediately modifies cardiovascular responses, as shown by its reduction of the cardiac response in Valsalva's manœuvre (Prichard, 1964); it reduces the reflex tachycardia during effort and the pulse pressure in overshoot, and preliminary experiments suggest (Hodge and Prichard, unpublished data) that propranolol has a similar action. While beta-receptor-blocking drugs have no hypotensive action following intravenous administration there is a slight hypotensive effect after short-term oral use of pronethalol (two to four weeks, Prichard, 1964 ; one week, Schröder and Werko, 1964). A considerable response has been obtained when either pronethalol or propranolol has been given for a prolonged period.

The tentative suggestion is made that these drugs act by reducing the cardiac response to stimuli which may be responsible for transient rises in blood-pressure. This is suggested by the modification of Valsalva's manœuvre. This damping-down of pressor responses may gradually condition the baroceptors to regulate the blood-pressure at a lower level in hypertensive and normotensive patients. However, the response to acute cardiovascular demands involving largely alterations in vascular tone is relatively unimpaired; this is manifest in the response to exercise and posture in patients receiving propranolol.

Initial studies suggest that propranolol has a useful hypotensive action, worthy of further study. It is relatively free from side-effects in the recommended dosage for hypertension.

\section{Summary}

Propranolol (Inderal) has been given to 24 patients, 16 of whom were hypertensives. Therapy was stopped in one patient after two days, as heart failure developed, otherwise it is relatively free from side-effects in the dosage recommended for hypertension.

Alone or in combination with other drugs it exerts a considerable hypotensive action in hypertensive and normotensive patients.

It is thought propranolol may exert its hypotensive action by interfering with the function of sympathetic nerves to the heart.

\section{REFERENCES}

Ahlquist, R. P. (1948). Amer. F. Physiol., 153, 586.

Black, J. W., Crowther, A. F., Shanks, R. G., Smith, L. H., and Dornhorst, A. C. (1964). Lancet, 1, 1080.

- and Stephenson, J. S. (1962). Ibid., 2, 311.

Dornhorst, A. C., and Robinson, B. F. (1962). Ibid., 2, 314

Paget, C. E. (1963). Brit. med. F., 2, 1266.

Prichard, B. N. C. (1964). Ibid., 1, 1227.

Prichard, B. N. C. (1964). Ibid., 1, 1227.

, Dickinson, C. J., Alleyne, G. A. O., Hurst, P., Hill, I. D., Rosen-

heim, M. L., and Laurence, D. R. (1963). Ibid., 2, 1226.

Schröder, G., and Werko, L. (1964). Clin. Pharmacol. Ther., 5, 159.

Stock, J. P. P., and Dale, N. (1963). Brit. med. F., 2, 1230.

\title{
Glucose-tolerance Test in Hypertensive Patients
}

\author{
E. R. NYE,* M.B., M.R.A.C.P., PH.D.
}

Brit. med. F., 1964, 2, 727-730

The association between diabetes and coronary artery disease is well recognized, and recently a high proportion of patients with coronary disease have been shown to have disturbed glucose-tolerance tests (Sowton, 1962) or increased insulin antagonism (Vallance-Owen and Ashton, 1963).

It is noteworthy also that even in the absence of glycosuria $14.5 \%$ of apparently normal subjects over the age of 50 years reported in the College of General Practitioners' survey (1963) had abnormal glucose-tolerance curves. It would be surprising if hypertensive patients, not necessarily suffering from overt diabetes, did not also show a proportion with abnormal glucosetolerance tests, and in view of the findings of Vallance-Owen and Ashton and of Sowton it is clearly important to establish the relationship between the two conditions.

\footnotetext{
* Wellcome Research Institute, Medical School, Dunedin, New Zealand.
} 